\title{
JUDICIALIZAÇÃO, ATIVISMO E EFETIVAÇÃO DE DIREITOS FUNDAMENTAIS
}

\author{
Judicialization, activism and effective of fundamental rights
}

\section{Ivete Maria de Oliveira Alves}

Mestre em Direito Constitucional pelo IDP - Instituto Brasiliense de Direito Público Brasilia/DF. Professora e Coordenadora do Curso de Direito do Instituto de Ensino Superior Cenecista, de Unai/MG. Advogada.

Recebido em: 01.03.2012

Aprovado em: 02.04.2012

ÁreA do Direito: Constitucional

REsumo: Este artigo é uma reflexão sobre o denominado ativismo judicial. A pesquisa tem suporte na existência da problemática confusão existente entre judicialização, ativismo e efetivação de direitos fundamentais; dentro de um contexto de jurisdição constitucional, modelo predominante de Estado, no mundo ocidental neste século XXI. Para responder ao problema e alcançar o objetivo de refletir sobre o ativismo judicial, busca-se sua inspiração no realismo jurídico; identifica-se as características de uma decisão ativista, seus limites e legitimidade; traça-se um paralelo entre ativismo e judicialização; para ao final abordar-se o papel do novo juiz, como ator principal neste cenário de jurisdição constitucional, que agora revela-se mais ativo e comprometido com as promessas constitucionais para concretização dos direitos fundamentais.
ABSTRACT: This article is a reflection on the socalled judicial activism. The research supports the existence of the problematic confusion between judicialization, activism and enforcement of fundamental rights, within a context of constitutional jurisdiction, the predominant model of state, in the western world this century. To address the problem and achieve the goal of thinking about judicial activism, we seek the inspiration in legal realism; identifies the characteristics of an activist decision, its limits and legitimacy, we draw a parallel between activism and the judicialization; to the and address is the role of the new judge, as the principal actor in this scenario of a constitution court, which now appears to be more active and committed to achievining the promises of constitutional rights. 
Palavras-chave: Ativismo - Jurisdição constitucional - STF.
KeYWords: Activism - Constitutional jurisdiction - Federal Court of Justice.

SumÁrio: 1. Introdução - 2. Do realismo jurídico ao ativismo judicial - 3. Características, limites e legitimidade do ativismo - 4. Judicialização e ativismo judicial - 5. 0 guardião das promessas -6 . Considerações finais -7 . Referências bibliográficas.

\section{INTRODUÇÃO}

Neste artigo tem-se como objetivo geral fazer uma reflexão sobre o denominado ativismo judicial. ${ }^{1}$ Dentro de um contexto de jurisdição constitucional, delimita-se como problema de pesquisa a seguinte questão: quais as relações entre judicialização, ativismo judicial e efetivação de direitos fundamentais? Para responder a esta pergunta e alcançar o objetivo geral, define-se como objetivos específicos: buscar inicialmente a inspiração do ativismo em um movimento conhecido nos Estados Unidos como realismo jurídico; fazer uma tentativa de identificar as características de uma decisão ativista, seus limites e legitimidade; traçar um paralelo entre ativismo e judicialização; para ao final abordar o papel do novo juiz, como ator principal neste cenário de jurisdição constitucional, que agora revela-se mais ativo e comprometido com a concretização das promessas constitucionais. Utiliza-se de método dedutivo com pesquisa bibliográfica.

\section{Do REALISMO JURÍDICO AO ATIVISMO JUDICIAL}

Antes de iniciar-se o estudo da judicialização e do ativismo judicial no Brasil, torna-se pertinente uma volta ao passado norte-americano, pois estes fenômenos têm características muito comuns, ao chamado, realismo jurídico estadunidense. No Brasil, Oscar Vilhena (1999) já ensinava que a nova postura do Judiciário é uma reação ao normativismo formalista e ingênuo com uma retomada ao realismo jurídico, defendido por Oliver W. Holmes (1995) e Jerome Frank (1970). Frank (1970) demonstra, com pesquisas empíricas, que os

1. A expressão ativismo judicial utilizada aqui, será também utilizada em outras partes do texto, no mesmo sentido em que é corriqueiramente atribuído nos discursos jurídicos e acadêmicos, ou seja, simplesmente quando os julgadores decidem fundamentados não apenas na letra da lei. 
juízes tratam diferentemente casos iguais, que colocam em suas decisões sua maneira de ver o mundo, refletindo seu temperamento, personalidade, educação e outras características pessoais. Para os realistas o direito é o que diz o juiz, são suas decisões judiciais.

"De fato, o realismo foi um movimento jurídico inspirado filosoficamente pelo pragmatismo que Holmes havia sido o primeiro a aplicar ao direito. Em seus escritos, e sobretudo em suas sentenças, Holmes havia aberto brechas no muro do antigo pensamento jurídico decimoníaco sobre as que, Pound primeiro, e os realistas depois, golpearam com tenacidade. Dito em termos menos metafóricos, Holmes havia enfatizado (e havia atuado sobre) muitos dos pontos que logo passaram a formar parte do programa realista. Entre eles, os seguintes: a separação, para efeito de análises, entre direito e moral (entre o ser e o dever ser do direito); a consideração primordial do direito como um instrumento para a consecução de fins sociais; a necessidade de trasladar o foco de atenção aos efeitos reais que produzem o direito sobre a sociedade; a consequente abertura dos estudos jurídicos aos estudos sociais empíricos; ou a desconfiança na capacidade das regras para determinar por si só os resultados dos processos jurídicos" (SEBAstiá, 2006, p. 19).

O que unia os realistas era uma atitude de fé combativa e valente no direito como formador da realidade social. O juiz Holmes chegou a escrever:

"Que é o direito?" Encontrareis que certos autores os digam que é algo distinto do que decidem os tribunais de Massachusetts ou da Inglaterra, que é um sistema da razão, que é dedução a partir de princípios de ética ou axiomas universalmente aceitos ou coisa parecida, que pode ou não coincidir com as sentenças judiciais. Mas se adotamos o ponto de vista de nosso amigo, o homem mal, veremos que a este importa pouco os axiomas ou deduções, mas que por outro lado lhe interessa saber que é que de fato tem resolvido os problemas dos tribunais de Massachusetts ou da Inglaterra. Eu opino de maneira bastante parecida. Eu entendo por 'direito' as profecias acerca do que os tribunais falam em concreto; nada mais nem nada menos" (Holmes apud Sebastí́, 2006, p. 20-21).

Para o juiz Holmes, o direito não advém da lógica, mas da experiência; concentra-se mais nas ações dos homens do que nos livros jurídicos. Busca em seus julgamentos identificar o sentido da norma, as circunstâncias sociais e atacar as questões problemáticas com profundidade. Esta natureza prática, nunca foi aceita pelos positivistas.

Sob um cotejo realista, o intérprete, ao buscar fundamentação para sua decisão, deve ter absoluta liberdade, deve estar desembaraçado de toda e qualquer moldura normativa previamente fixada. Não faz sentido o debate entre 
objetivismo e subjetivismo, uma vez que o aplicador não se aterá ao direito preexistente. Mas não em uma atuação livre ou inconsequente, mas diretamente ligada às fontes materiais, ou seja, aos fatores sociais. "Substitui-se o subjetivismo legalista da escola da exegese pelo subjetivismo do magistrado" (RAmos, 2010, p. 75).

O realismo não despreza as fontes formais do direito, apenas as considera como fatos sociais. O direito propriamente dito somente aflora depois de sua concretização na decisão judicial. É uma nítida aproximação do realismo ao pragmatismo jurídico.

"O direito tornar-se-ia positivo ou positivado após ser aplicado pelo juiz e não quando promulgado pelo legislador. Ou seja, antes de ser aplicada, a norma jurídica constituiria apenas um dentre os diversos recursos e materiais dos quais o juiz pode se valer. Ele seria, sim, uma fonte autoritativa, mas não seria ainda uma norma válida. $\mathrm{O}$ que confere validade às normas para os pragmatistas é a sua aplicação" (Pogrebisnschi, 2000, p. 128).

O juiz pragmatista preocupa-se fundamentalmente com a consequência de sua decisão. Antes de decidir ele avalia todas as possibilidades de decisão e escolhe a que lhe parecer melhor.

O ceticismo atual com relação à produção da norma faltante é o mesmo que dominava os realistas que não acreditavam na eficiência de normas gerais e abstratas, produzidas sem considerar as peculiaridades do caso concreto. Valorizam o intérprete e não o legislador.

Há que se reparar que o intérprete também traz consigo suas pré-compreensões e seus preconceitos, que podem macular a sua decisão com sua arbitrariedade, tornando-a ilegítima.

"Quem busca compreender está exposto a erros de opiniões prévias que não se confirmam nas próprias coisas. Elaborar os projetos corretos e adequados às coisas, que como projetos são antecipações que só podem ser confirmadas nas coisas, tal é a tarefa da compreensão. Aqui não existe outra objetividade a não ser a confirmação que uma opinião prévia obtém através de sua elaboração. Pois o que é que caracteriza a arbitrariedade das opiniões prévias inadequadas senão o fato de que no processo de sua execução acabam sendo aniquiladas? A compreensão só alcança sua verdadeira possibilidade quando as opiniões prévias com as quais iniciam não forem arbitrárias. Por isso, faz sentido que o intérprete não se dirija diretamente aos textos a partir da opinião prévia que lhe é própria, mas examine expressamente essas opiniões quanto à sua legitimação, ou seja, quanto à sua origem e validez" (GADAMER, 2007, p. 356).

O grande problema do realismo e pragmatismo é a insegurança jurídica, o medo da excessiva liberdade do julgador, o que foi percebido desde sua con- 
cepção. Para os legalistas, o realismo com sua discricionariedade desenfreada era um pesadelo horroroso. Para o bem da segurança jurídica, na elaboração da norma-decisão, o intérprete deve ater-se aos parâmetros dogmáticos estabelecidos pelo ordenamento.

Bobbio (2003) aborda o realismo jurídico como uma contraposição ao jusnaturalismo que fazia uma concepção ideal do direito e do positivismo com sua concepção formal. Os realistas ou conteudistas não veem o direito como um dever ser, mas como efetivamente é. E nem como complexo de normas válidas, mas como normas efetivamente aplicadas em uma determinada sociedade.

Dworkin (1999) ensina que não se pode supor que realistas e pragmatistas ignorem por completo a presença normativa limitadora no fenômeno jurídico, sob a qual se guiarão na fundamentação de suas decisões, que apenas se ampliará pela lógica das necessidades sociais.

O poder discricionário do juiz existe, mas para Dworkin (2002) não é tão forte assim, sua resposta ao julgar um caso judicial será baseada em elementos estruturantes do sistema jurídico e não em seus próprios princípios e valores; ou seja, é um poder discricionário em sentido fraco. Reside aí a legitimidade de sua atuação.

No caso brasileiro pós 1988, a tarefa do magistrado é bastante complexa, pois a Constituição é nitidamente compromissária e imbuída de questões valorativas e principiológicas. Realidade acrescida de um contexto social onde as desigualdades econômico-sociais são enormes e muitos dos direitos fundamentais previstos no texto da Carta Maior não passam de meras promessas carentes de concretização. Ao optar por uma decisão de perfil ativista, o representante do Poder Judiciário retoma aspectos nitidamente realistas e pragmatistas do direito; preocupa-se com as consequências da decisão, com a concretização de princípios e direitos constitucionais, com sua possibilidade de cumprimento e com seus reflexos jurídicos, políticos e sociais.

\section{Características, limites e legitimidade do ativismo}

O juiz que imbuído da vontade de fazer concretizar direitos, decide, fundamentando sua decisão em outros fundamentos a mais que a mera letra expressa da lei, é frequentemente taxado de ativista e até mesmo arbitrário, pois vai além do seu poder de meramente julgar aplicando a lei. Assim, invade a esfera de outro Poder do Estado. Vale ressaltar que o mundo moderno ainda não conseguiu uma forma mais eficaz de se evitar as ditaduras do que a divisão do Poder Estatal. O poder é uno, porém deve ser dividido entre diferentes titulares, para se evitar abusos ditatoriais e aprimorar o Estado de Direito. 
Segundo Branco (2009), as duas medidas utilizadas com o objetivo de conter o arbítrio e impor a moderação ao governante são a separação dos Poderes e a proclamação dos direitos fundamentais. Ressalta, porém, que a separação dos Poderes, conforme inicialmente concebida, servia para constranger o poder de julgar a uma posição de menor tomo.

A Revolução Gloriosa marcou o início da supremacia do Parlamento em contrapeso à Coroa. Foi reafirmada a titularidade do rei no Executivo, mas o Bill of Rights limitou-lhe os poderes. Esta arquitetura foi refinada por Montesquieu (1979), que defendia a Monarquia, mas embebida em princípios liberais, especialmente na separação dos Poderes, como o mais eficaz instrumento contra o despotismo absolutista. O homem que possui poder é tentado a abusar dele, por esta razão é necessário que um poder freie o outro poder. Montesquieu identifica três Poderes no Estado: o Executivo, o Legislativo e o Judiciário. Sendo que o Executivo ficaria a cargo do rei; o Legislativo dividido entre a Câmara alta e a Câmara baixa, um neutralizaria o outro. Estes seriam efetivamente os três Poderes, pois o Poder Judiciário não seria, na concepção de Montesquieu, um Poder independente, pois neutralizaria a si mesmo, uma vez que transitório e vinculado à lei, não podendo moderar nem a força e nem o rigor da lei.

"(...) se os tribunais não devem ser fixos, os julgamentos devem sê-lo a tal ponto que nunca sejam mais do que um texto exato da lei. Se fosse uma opinião particular do juiz, viver-se-ia na sociedade sem saber precisamente os compromissos que nela são assumidos" (Montesquieu, 1979, p. 120).

A preocupação fundamental em Montesquieu é a segurança jurídica, a clareza dos compromissos assumidos, questão essencial para a vida em sociedade e, principalmente evitar o absolutismo do soberano.

Rosseau (1981) relata que Roma em todo seu esplendor, foi vítima de crimes e tirania em razão de ter reunido nas mesmas pessoas a autoridade legislativa e o Poder soberano.

Entre os constitucionalistas brasileiros, destaco o Prof. Manoel Gonçalves Ferreira Filho (1988) que entende inegável a necessidade de separação dos Poderes estatais de forma absoluta:

"A justicialidade pressupõe a separação absoluta entre quem diz o direito e quem o edita ou executa. Ou, pelo menos, se o ideal é inatingível, a maior separação ou especialização possível entre jurisdição, legislação e administração. Assim, é inegável existir um vínculo entre a fórmula clássica que é a separação de Poderes e o Estado de Direito" (Ferreira Filho, 1988, p. 33).

Nestes primeiros anos do século XXI, esta continua sendo uma preocupação dos Estados Constitucionais. Limitar o poder para evitar abusos. Um poder 
depende do outro, perpassam-se. Ademais, o Poder estatal é único; porém, deve estar dividido para garantir que será exercido na defesa do povo, seu titular originário, legítimo e soberano.

Sustenta Bruce Ackerman (2009) que o modelo de Estado presidencialista facilita a concentração de poder nas mãos do Chefe do Executivo, facilitando o surgimento de ditaduras, o que é mais difícil no sistema parlamentar. Pois, no sistema parlamentar, o Chefe do Governo está atrelado à maioria parlamentar, gozando de menor poder individual que o Presidente, modelo que predomina no continente americano, sob a influência dos Estados Unidos da América. Acontecimentos recentes em vários países da América Latina parecem confirmar esta tese; presidentes têm consolidado longa permanência no poder, legitimados por instrumentos democráticos.

Tradicionalmente, ao Presidente, ou Primeiro Ministro, Chefe do Poder Executivo, cabe executar a lei e movimentar a máquina administrativa do Estado; ao Judiciário cabe julgar os conflitos surgidos, fazendo cumprir a lei; e ao Legislativo cabe elaborar a lei. Garapon (2001) demonstra que em muitos países já não é o Parlamento quem elabora a lei, mas especialistas tecnocratas, que não representam a vontade geral do povo soberano. Este fato certamente contribui para a ineficácia dos textos legais, que são elaborados mediante o jogo político de coalizões e alianças que se afastam da vontade geral. A lei se torna um produto inacabado e necessita da atuação do juiz para aproximá-la da realidade do povo.

Outro motivo que enfraquece a lei de um Estado é a relevância que se tem dado, em um contexto mundial, às fontes supranacionais do direito. O direito comunitário na União Europeia, as Convenções e Tratados Internacionais, especialmente os Tratados de Direitos Humanos, a Lex Exportiva, a Lex Mercatori, enunciam princípios que norteiam a aplicação do direito aos casos concretos de forma supranacional, não podendo mais o juiz decidir os casos concretos, a ele submetidos, isolado do contexto jurídico global.

No Brasil, o princípio da separação dos Poderes tem status de cláusula pétrea, imune a emendas, reformas ou revisões. Apesar deste sentido inicial forte, modernamente esse velho dogma da sabedoria política tem sofrido flexibilização diante da necessidade imperiosa de ceder espaço para a legislação do executivo através de medidas provisórias, bem como da atuação ativista dos tribunais (MENDEs et al, 2008).

Um Estado Constitucional é aquele que se rege por um texto maior, dotado de respeito pelos seus súditos, que nutrem por este Estado um sentimento de pertença que legitima suas ações. Nem sempre o Estado Constitucional foi um 
Estado Democrático; nem sempre o Estado Constitucional de Direito foi um Estado onde o direito fosse comum a todos os seus cidadãos. Hitler fundamentava suas ações discriminatórias no Estado de Direito Constitucional alemão.

Michel Rosenfeld (2009, p. 189) ressalta que: "Em essência, o Estado de Direito requer que todas as relações e conflitos interpessoais dentro do Estado sejam sujeitas à regras e padrões regulares, aplicáveis de modo geral, e que nenhuma pessoa, nem mesmo o Chefe do Estado, esteja acima deles". Em um Estado de Direito, a lei deve ser a mesma para todos, independente de suas características pessoais, fortuna, poder, raça ou sua fé.

Repare que a humanidade tem trilhado longos caminhos em busca de um modelo de Estado que permita uma maior harmonia entre as pessoas. Estes caminhos têm sido marcados por longos períodos de exploração dos fracos pelos fortes; revoluções sangrentas são levadas a efeito em nome da liberdade e igualdade. Certo é que o indivíduo abriu mão de sua autonomia através de sua submissão ao Estado, por reconhecer que no Estado de Natureza, onde todos mandam em todos, não há harmonia possível. John Locke (Locke, 2002) ensina que no Estado de Natureza qualquer homem pode castigar outro homem que tenha praticado ato contrário à boa convivência. De onde advém a ideia de que o governo civil é o melhor remédio para os inconvenientes de cada homem ser juiz em causa própria.

No Estado de Direito, o soberano se submete ao direito por ele mesmo criado. E este direito tem como fonte principal o Texto Constitucional. Ensina Canotilho (1997) que a Constituição se refere à organização da comunidade política que escolhe e define parâmetros de existência de um determinado modelo de Estado. Criando o Estado Constitucional. Para os constitucionalistas modernos não se concebe um Estado Constitucional que não tenha em sua base a democracia e o direito. Em outras palavras, o direito deve ser escolhido pelo povo de forma transparente e livre, para depois tornar-se lei, e abranger a todos: governo e cidadãos.

A escolha dos direitos a serem inseridos no Texto Constitucional é feita pelo povo, através de seus representantes eleitos; ${ }^{2}$ são os chamados legisladores originários que atuam em nome do povo; este sim, o legítimo titular do poder soberano de escolher como pretende viver e a que normas de compor-

2. Segundo Chauí (2007), a política brasileira, ainda padece de males como o paternalismo, populismo, clientelismo e troca de favores, pois não conseguiu maturidade suficiente para se desvincular da origem de sagração do governante, que considerava o governo como representante de Deus e não do povo. 
tamento aceita submeter-se. Somente será legítimo o Estado onde os súditos são transformados em cidadãos e participam livremente das escolhas políticas. "É preciso perquirir se o itinerário seguido pelo Estado, e a forma jurídica por ele empreendida, resultaram em um processo político de inclusão e reconhecimento que logrou transformar súditos em cidadãos" (Moreira, 2007, p. XIII).

Os cidadãos, ao elegerem livremente seus representantes, outorgam-lhes poderes de promulgarem a Constituição e a ela se submetem.

"Assim, o poder soberano dos sujeitos de direito é obra da liberdade e da igualdade. Sendo criação de todos os cidadãos, torna também universal a obrigatoriedade jurídica (isonomia). Uma obrigatoriedade, prescritiva e a posteriori, que por meio dos sujeitos de direito institucionaliza a liberdade e a igualdade em sociedades complexas e que têm no direito o medium ao mesmo tempo normativo e democrático" (Moreira, 2007, p. 36).

Assim, a Constituição deve ser obedecida por todos, pois representa a vontade da maioria do povo, legítimo titular do poder originário. Larry D. Kramer (2009) chega a defender que inclusive o significado, interpretação e controle da constitucionalidade seja realizado pelo povo, é o que ele chama de "constitucionalismo popular".

"Assim, o constitucionalismo popular pauta-se em, e, depende de, uma cultura política na qual autoridades públicas, líderes comunitários e cidadãos comuns acreditam na distinção entre lei e política, compartilham um conjunto de convenções sobre como argumentar dentro de cada domínio e levam à sério a diferença de papéis que isso produz. Em um sistema de constitucionalismo popular os participantes respondem a diferentes argumentos em cada cenário e tratam questões de interpretação constitucional como problemas 'jurídicos' que podem ser resolvidos apenas pelo recurso à 'lei', assim como entendida pelas normas interpretativas, tais como teoria, história e precedente" (KRAMER, 2009, p. 89).

No Brasil, o legislador constituinte de 1988 não fez menção ao constitucionalismo popular. Ao revés, parece até mesmo ter desconfiado dos legisladores futuros. Quis blindar o Texto Constitucional contra possíveis reformas que poderiam propiciar novas ditaduras; dotou o Texto de instrumentos de reserva, as chamadas cláusulas pétreas; atribuiu a tarefa de interpretar a Constituição e principalmente de controlar a constitucionalidade das normas futuras ao Poder Judiciário.

Repare que o Estado brasileiro instituído em 1988 adotou o sistema de controle misto. Porém, deu maior ênfase ao controle concentrado ou abstrato, permitindo que todas as controvérsias constitucionais relevantes sejam subme- 
tidas ao STF. Sob a influência do mundo europeu do pós-guerra, tem pautado seu cenário jurídico pela presença do movimento chamado neoconstitucionalismo. ${ }^{3}$ Este movimento se caracteriza pela efetiva proteção às normas constitucionais e prestígio máximo aos direitos fundamentais inseridos na Constituição (BRANCO, 2009).

Desta forma, cabe aos tribunais o papel de garantir que estes direitos sejam materializados e não se tornem meros símbolos transcritos na Norma Constitucional. O juiz, ao decidir um caso concreto, passa a exercer função de intérprete do texto, na tarefa de extrair sua essência e fazer justiça ao jurisdicionado.

Em um Estado Constitucional Democrático de Direito o controle jurisdicional de constitucionalidade é apenas uma medida para dar coerência e unidade ao sistema jurídico. Não prescinde do Parlamento, local adequado para o debate e deliberações na busca de consenso.

"Somente na democracia é que a legitimidade se organiza de modo que os Poderes se submetam à orientação que decorre das urnas. Foi assim que no segundo livro, obedecendo a lógica que é a democracia que converte o arbítrio estatal em poder, foi levantado o problema dos limites do controle de constitucionalidade, de modo que ficasse claro que tal controle é apenas uma medida apta a institucionalizar a coerência entre os atos estatais e a Constituição e não um instrumento com o qual se valida a submissão da política a um governo dos juízes, despótico por definição" (Bigonha; Moreira, 2010, p. 1).

Ao dar coerência ao sistema, o controle jurisdicional de constitucionalidade pauta-se por decisões fundamentadas e fincadas no Texto Constitucional e na defesa dos direitos fundamentais. Sua legitimidade depende de seus limites, para se evitar um Estado Judicial de Direitos.

Para Bigonha e Moreira (2009), o risco de um Estado Judicial de Direitos no Brasil é iminente, a semelhança do "governo dos juízes, ${ }^{4}$ uma vez que houve

3. Sob esse título, autores de diversos matizes ideológicos, veem no modelo constitucional europeu do pós-guerra um paradigma singular na história, marcado pela materialização das Constituições, expressa por normas constitucionais densas de conteúdos significativos, proclamando direitos individuais substantivos, e não apenas cuidando de regular aspectos de procedimento do poder. O momento "neoconstitucionalista" também é tido como peculiar pela efetiva proteção das normas constitucionais por meio de uma judicatura independente dos órgãos legiferantes (BRANCO, 2009, p. 130-131).

4. O chamado governo dos juízes existiu nos EUA por volta dos anos de 1937, foi protagonizado por uma Suprema Corte que se opõe às novas políticas sociais e econômicas tomadas pelo Executivo e pelo Legislativo federais (Oliveira, 1998). 
uma apropriação pelos juristas, da Carta Política de 1988, quando a democracia, a política e o Parlamento foram progressivamente mitigados e em seu lugar houve a construção de uma teoria que, a pretexto de proteger os direitos fundamentais, os substituiu pela supremacia judicial, operada pelo controle de constitucionalidade e pela mutação constitucional. Neste quadro, segundo estes autores, o Parlamento caminha para ser tido como desnecessário. Apesar de legítimo, uma vez que é a vontade expressa através do mandato que lhe é conferido pelos cidadãos que o institui. Os autores chegam a afirmar que a técnica está a substituir a democracia.

A Constituição brasileira de 1988 instituiu não apenas um Estado Democrático, mas um Estado Democrático de Direito. A existência harmoniosa destas duas concepções políticas não se dá sem ambiguidades; para Oscar Vilhena (1999) esta tem sido a principal meta do constitucionalismo moderno e contemporâneo. A tensão é constante entre os instrumentos democráticos e a necessidade de proteção dos direitos das minorias. E quanto maior for o número de princípios e direitos inseridos na Constituição, mais amplas serão as atribuições de um Tribunal Constitucional.

Para Eduardo Appio: "A legitimidade das decisões judiciais advém, portanto, da ampliação do debate democrático sobre o conteúdo dos princípios e valores constitucionais" (ApPIO, 2008, p. 21).

O rol de direitos e princípios constitucionais colocados a salvo das decisões majoritárias, permeia todo o Texto Constitucional. O que conduz a um Tribunal Constitucional muito atuante na vida dos cidadãos, e cujas decisões envolvem questões controversas, morais e valorativas, de grande repercussão política na sociedade.

Assim, o Judiciário brasileiro oscila entre uma postura procedimentalista ${ }^{5}$ democrática e uma postura substancialista ${ }^{6}$ em defesa dos direitos fundamentais, o que certamente conduz a questões intrincadas.

5. Adeptos da postura procedimentalista: Ely, John Hart. Democracy and distrust: a theory of judicial review. Cambridge: Harvard University Press, 1997; Habermas, Jürgen. Direito e democracia entre facticidade e validade. Rio de Janeiro: Tempo Brasileiro, 1997. vol. 1. Hä̈erle, Peter. Hermenêutica constitucional a sociedade aberta dos intérpretes da Constituição: contribuição para a interpretação pluralista e procedimental da Constituição. Trad. Gilmar Ferreira Mendes. Porto Alegre: Sergio Antonio Fabris Ed., 2001 (LeAL, 2010).

6. Adeptos da postura substancialista: Rawls, John. A theory of justice. Cambridge: Belknap Press, 1999; Rawls, John. O liberalismo político. Trad. Dinah de Abreu Azevedo. São Paulo: Ática, 2000; Dworkin, Ronald. Taking rights seriously. Cambridge: 
Werneck Vianna (1999) designa no eixo procedimentalista, J. Habermas e A. Garapon. Desse eixo viria a compreensão de que a invasão da política pelo direito, mesmo que em nome da igualdade conduziria a uma perda de liberdade, ao paternalismo estatal, à clericalização da burocracia e a uma Justiça de salvação; enquanto que a função originária do Tribunal Constitucional seria a de zelar pelo respeito aos procedimentos democráticos para uma formação de opinião e manifestação da vontade política, a partir da própria cidadania e não a de se arrogar o papel de legislador político. Não havendo lugar para ativismo judicial. Este, em Garapon somente se pratica sob um caráter social e se exerce estritamente no campo da sociabilidade. Sob este paradigma os problemas empíricos devem ser saneados fora do meio judiciário, através de políticas públicas destinadas a sua viabilização.

Por outra banda, Werneck Vianna (1999) designa como eixo substancialista, M. Cappelletti e R. Dworkin, para estes as novas relações entre direito e política, particularmente por meio da criação jurisprudencial do direito são inevitáveis e não estranhos à tradição democrática e, sim, são uma efetiva e necessária extensão dessa tradição a setores ainda pouco integrados à sua ordem e ao seu ideário.

Embora compatibilizar a vontade da maioria com os princípios constitucionais coloque em termos claros a oposição entre democracia e justiça, este conflito é meramente aparente. Appio (2008), citando Dworkin, conclui que a democracia constitucional é compatível com uma concepção substancial dos juízes acerca de valores morais que os autoriza a adotarem posições contra majoritárias. Na América Latina, onde a democracia surge de ditaduras e não conseguiu, ainda, dar condições educacionais e culturais a toda sua população para exercer com independência seu direito ao voto, é normal que o povo deposite no Judiciário suas expectativas no que tange ao regime democrático e das garantias individuais, através de uma verdadeira divinização das concepções morais e filosóficas dos juízes constitucionais.

Segundo Saul Tourinho Leal (2010), sob uma postura procedimentalista, a jurisdição constitucional atua como instrumento e defesa do procedimento democrático, não podendo aplicar na solução de controvérsias que aprecia princípios de justiça. Sua função seria a de mera observadora do correto fun-

Harvard University Press, 1977; Dworkin, Ronald. Freedom's law, the moral reading of the American Constitution. Cambridge: Harward University Press, 1996; Dworkin, Ronald. O império do direito. Trad. Jefferson Luiz Camargo. São Paulo: Martins Fontes, 1999 (LeaL, 2010). 
cionamento do processo político. Ao revés, sob um cotejo substancialista, a jurisdição constitucional é instrumento de defesa dos direitos fundamentais.

Independente do tipo de Estado, o novo constitucionalismo, para contribuir com a formação de um Estado capaz de assegurar os enquadramentos políticos e institucionais para a prossecução do desenvolvimento sustentável e equitativo; deverá, segundo Canotilho (2006), somar-se aos princípios tradicionais do Estado: proteção, segurança e confiança jurídicas; princípio da proporcionalidade e do acesso ao direito. Novos princípios, como o princípio da transparência dos trabalhos das instituições, dos órgãos e dos mecanismos do Estado; princípio da coerência entre as diferentes políticas e ações que um Estado promove no âmbito político, econômico, social, cultural, ambiental e internacional; princípio da abertura especialmente vocacionado para a busca de soluções múltiplas de governo; princípio da eficácia das ações políticas e finalmente, o princípio da democracia participativa. Estes novos princípios devem ser acrescentados, segundo o paradigma da geologia, formando uma nova camada no direito constitucional.

Certamente, em um Estado norteado por todos estes princípios, o homem comum deixará de ser apenas súdito, para ser realmente um cidadão comprometido com o direito e com a democracia. Ademais, a tarefa de defender os direitos constitucionais não é tarefa apenas dos magistrados, mas de toda a sociedade brasileira.

\section{JUdiCIALIZAÇÃO E ATIVISMO JUDICIAL}

No Estado Constitucional, a Constituição é a norma fundamental, que resulta do amplo debate que deve existir antes de sua promulgação e representa o compromisso feito pelos legisladores originários, representando a vontade geral. Lassale (1998) diz que a Constituição de um país expressa as relações de poder nele dominantes, existindo uma correlação de forças que resulta na Constituição real do país; chega a afirmar que a Constituição jurídica é mero pedaço de papel que se rasga frente à Constituição real. Todavia, nem sempre o confronto entre as duas deve dar-se em favor da Constituição real. Aceitar que a Constituição jurídica seja mera folha de papel é atribuir a ela função indigna e medíocre de justificar as relações dominantes.

"Assim, o direito constitucional não estaria a serviço de uma ordem estatal justa, cumprindo-lhe tão somente a miserável função - indigna de qualquer ciência - de justificar as relações de poder dominantes" (Hesse, 1991).

A Constituição não apenas organiza o Estado, vai além, e estabelece em que tipo de Estado o povo pretende viver. Se é um Estado autoritário ou democráti- 
co; se tende à justiça social efetiva ou apenas demagógica; se condena qualquer legislação ou atitude que deseja paralisar o progresso através de ditaduras burocrático-policiais. Conforme afirma o Prof. Roberto Lyra Filho (2007), sejam elas cínicas e ostensivas ou hipócritas e disfarçadas. Certo é que a Constituição institui o tipo de Estado a que se submeterá seu povo.

A Constituição possui uma pretensão de eficácia, e torná-la efetiva é tarefa de todas as instituições, particularmente do Judiciário, que através de sua Corte constitucional assume esta tarefa com maior clareza, ao adotar posturas de interpretação ativas do Texto Constitucional em suas decisões, procurando garantir a concretização de direitos dos seus jurisdicionados. Deixa de ser mero legislador negativo e assume nova postura de perfil criativo na defesa dos direitos constitucionais. Fato que tem provocado caloroso debate em razão do princípio constitucional da separação dos Poderes.

"Nesse quadro de mudança do papel dos juízes, como se conceberia a função jurisdicional, tradicionalmente deferida ao Poder Judiciário? A interpretação do direito feita pelos juízes em suas decisões e sentenças equiparar-se-ia à atividade criativa do direito, desenvolvida pelo legislador? Se isso é verdade, em que então elas se diferenciam? Estaria o Poder Judiciário, ao contrário, invadindo as funções dos dois outros?" (SIFUentes, 2005, p. 75).

Estas questões têm fomentado intensos debates acadêmicos e políticos, são certamente perguntas que devem conduzir a profundas reflexões. Afinal, quem deve garantir que a Constituição seja cumprida? Quem deve ser o guardião da Constituição?

Essa questão foi o tema de rico debate entre Hans Kelsen e Carl Schmitt, sobre o caráter da crise político institucional que agitava a Europa e particularmente o Reino alemão, sob a Constituição de 11.08.1919, conhecida como a Constituição de Weimar. O escritor austríaco desempenhou papel relevante na instituição e funcionamento do Tribunal Constitucional alemão, fazendo esforços no sentido de concretizar as garantias constitucionais, as quais considerava o núcleo da Constituição e que deveriam ser defendidas pelo Tribunal Constitucional. Ao revés, Schmitt sustenta que o Presidente do Reino, deve ser o defensor ou guardião da Constituição; pois possui o respaldo da maioria do povo e detém um poder chamado "neutro" de agir sem atingir a democracia (GASIÓ, 1995). Regimes totalitários se apropriaram das ideias de Schmitt para justificar seus governos minoritários.

No Brasil a judicialização da política tem inúmeras causas. O Prof. Barroso (2009) destaca entre elas: a redemocratização que culminou com a Constituição de 1988, que fortaleceu o Judiciário e aumentou a demanda por justiça 
na sociedade; a segunda causa foi a constitucionalização abrangente, ou seja, muitas matérias foram agora trazidas para o Texto Constitucional, numa tentativa de garantir sua aplicação; a terceira causa é o sistema brasileiro de controle de constitucionalidade, que combina os sistemas americano e europeu, com o controle difuso ou concreto exercido por qualquer juiz ou tribunal e controle concentrado ou abstrato exercido pelo STF, que pode alcançar qualquer questão política ou moralmente relevante.

Vianna (1999) atribui o crescimento da judicialização de questões políticas e sociais, à adoção e desenvolvimento do sistema de controle abstrato de constitucionalidade, com a convocação da chamada comunidade de intérpretes da Constituição como consequência de um amadurecimento do judiciário brasileiro, que assume seu compromisso com os direitos da cidadania e com a racionalização da administração pública. Esta judicialização representa o descontentamento das minorias contra as maiorias parlamentares. Contudo, a Corte tem sido cautelosa evitando inicialmente o ativismo judicial; foi migrando silenciosamente da posição de ator coadjuvante na produção legislativa para a de guardião da Carta Constitucional e dos direitos fundamentais da pessoa humana. A judicialização da política decorre da vontade do legislador constituinte que elaborou uma Constituição analítica que permite discussões de origem política e moral nas ações judiciais.

Quanto mais os cidadãos conhecerem os seus direitos contidos na Constituição de 1988 e os instrumentos de controle de constitucionalidade, mais ativa será a participação do Judiciário nas decisões políticas do país. Garapon (2001) teme que um excesso de participação do Judiciário possa ser nocivo para o Estado Democrático, uma vez que poderá conduzir a uma ditadura de minorias, ou até mesmo a uma falta de identidade do povo; lembra que ao se multiplicarem os direitos, corre-se o perigo de perder-se a noção do direito. Porém, a judicialização da política não é ativismo judicial. Barroso (2009) explica que os dois institutos são primos, porém são distintos. A judicialização decorre do modelo constitucional adotado, enquanto o ativismo decorre da vontade, de uma atitude do magistrado na escolha de um modo específico e proativo de interpretar a Constituição, normalmente em situações de retração do Poder Legislativo, em que existe um certo descolamento entre a classe política e a sociedade civil, impedindo que as demandas sociais sejam atendidas de maneira efetiva.

"A ideia de ativismo judicial está associada a uma participação mais ampla e intensa do Judiciário na concretização dos valores e fins constitucionais, com maior interferência no espaço de atuação dos outros dois Poderes. A postura ativista se manifesta por meio de diferentes condutas, que incluem: (i) a apli- 
cação direta da Constituição a situações não expressamente contempladas em seu texto e independentemente de manifestação do legislador ordinário; (ii) a declaração de inconstitucionalidade de atos normativos emanados do legislador, com base em critérios menos rígidos que os de patente e ostensiva violação da Constituição; (iii) a imposição de condutas ou de abstenções ao Poder Público, notadamente em matéria de políticas públicas" (BARroso, 2009, p. 6).

As decisões ativistas buscam mais que defender a Constituição, trata-se de garantir os enunciados prospectivos desse texto fundante, buscando sua eficácia. Aqui está sua importância para a ordem social estabelecida na Carta Maior. Uma postura ativista da Corte pode contribuir eficazmente para a realização das promessas contidas na ordem social.

A dificuldade de se identificar o ativismo judicial está na dificuldade de se interpretar o Texto Constitucional. A Corte será ativista apenas quando ultrapassa os limites dados pelo texto normativo, ultrapassando os meros cânones aceitos pela interpretação. O que fatalmente dependerá de que conceito o tribunal tem acerca do direito (Valle, 2009).

Dworkin (1999) concebe o direito sob a perspectiva da integralidade, em que se frise a coerência. Assim, o juiz deve identificar direitos e deveres de cidadãos que vivem em uma comunidade regida por princípios e regras comuns. Devendo observar os precedentes elaborados em momentos anteriores, como romances escritos por diversos autores, dos quais um completa o outro, e conhecendo a comunidade, seus desejos e expectativas, encontra uma resposta coerente, mesmo para os casos difíceis. Ressalte-se que esta resposta nem sempre se dará com base em regras, mas também em princípios, e será dada por um super juiz, chamado Hércules. Kelsen (2007) identifica o direito com a norma que estabelece uma conduta a ser seguida, pois ao contrário, ocorrerá a aplicação de uma sanção, independente de seu conteúdo, sendo que as normas são dispostas hierarquicamente; uma é pressuposto de validade da outra, as quais coexistem formando um sistema. Luhmann (1983) entende o direito ligado a sua função, sendo uma generalização de expectativas fáticas orientadas na busca de uma estabilização social através da garantia das expectativas normativas ou contrafatuais; Holmes (apud VAlLe, 2009) afirma que todo direito é criado pelos tribunais; para Hart (apud VAlLE, 2009) a criação do direito está circunscrita à penumbra que envolve o núcleo de certeza das proposições jurídicas em geral.

Parece-me então, que o ativismo deriva do sentido subjetivo das normas. E também vai acontecer quando o Judiciário atua na omissão do legislador, em defesa das minorias, em defesa de direitos e valores que não estão na lei. 
Bredlay Cânon (1983) fixa cinco critérios que determinam se uma decisão será ativista: Primeiramente, deve-se considerar ativista uma decisão que apresenta um alto grau de superação das decisões tomadas pelo Legislativo e Executivo. Estas decisões serão tomadas na defesa dos direitos fundamentais, mesmo assim, podem causar uma tensão entre democracia e jurisdição constitucional. No segundo critério, o autor americano cita a ruptura com a jurisprudência anterior, em outras palavras, ruptura com a estabilidade interpretativa. Repare que toda mudança paradigmática deve ser fundamentada com clareza, sob pena de se tornar obscura e acusada de ilegitimidade. Como terceiro critério, aponta a fidelidade interpretativa, ou seja, a nova interpretação foge ao sentido comum das palavras. Não está de acordo com o consenso anterior. Como quarto critério, a decisão ativista interferirá no jogo democrático, se apenas garante direitos de minorias insulares, a decisão não seria ativista. $O$ quinto e último critério estabelecido é que a decisão ativista é aquela que inova o direito, criando direito antes inexistente. As decisões objeto deste estudo parecem ativistas segundo os critérios estabelecidos pelo autor. Sob este cotejo, talvez possamos até chamar todas as decisões judiciais que garantam a efetividade dos direitos sociais de ativistas.

Por outro lado, para Saul Leal (2010), se o magistrado assegura direitos constitucionais, a decisão não é ativista; apenas faz cumprir a Constituição.

Para o Prof. Elival Ramos (2010), o ativismo ocorre quando acontece um desrespeito aos limites normativos substanciais da função jurisdicional, fatalmente contribuindo para o enfraquecimento democrático. ${ }^{7}$

No Brasil o STF tem demonstrado sua posição no sentido de contribuir para garantir direitos constitucionais, como no voto do Min. Gilmar Mendes na ADIn 1.351/DF:

“(...) É possível antever que o STF acabe por se livrar do vetusto dogma do legislador negativo e se alie à mais progressiva linha jurisprudencial das decisões interpretativas com eficácia aditiva, já adotadas pelas principais Cortes Constitucionais europeias. A assunção de uma atuação criativa pelo Tribunal poderá ser determinante para a solução de antigos problemas relacionados à inconstitucionalidade por omissão, que muitas vezes causam entraves para a efetivação de direitos e garantias fundamentais assegurados pelo Texto Constitucional" (ADIn 1.351/DF).

7. Para a autora deste trabalho, as decisões proferidas nos MI 670, 708 e 712 apenas deram condições de concretização de um direito fundamental já previsto no Texto Constitucional. Em outras palavras, se não criou direito novo, não são ativistas. 
Esta postura representa uma corajosa ruptura de paradigma dentro da Corte brasileira, razão por que as decisões ativistas têm sido robustamente fundamentadas. Frise-se que em todas elas o Supremo foi provocado a se manifestar e não poderia deixar de prestar a tutela jurisdicional.

Para contribuir com a concretização do modelo de Estado instituído pela Constituição, esta postura ativista deve obedecer a parâmetros e limites constitucionais. Para Garapon (2001), o ativismo evidencia-se quando o juiz ao decidir, faz escolhas fundamentadas na sua vontade de acelerar a transformação social ou, ao contrário, de travá-la. Seja progressivo ou retrógrado, a questão é crucial sob o aspecto do princípio da separação dos Poderes, que é um dos pilares de sustentação do moderno Estado Constitucional e Democrático de Direito, instituído no Brasil pela Constituição de 1988.

\section{0 GUARDIÃO DAS PROMESSAS}

Neste modelo de Estado Constitucional e Democrático de Direito, o soberano submete-se ao direito por ele mesmo criado. O Judiciário se torna uma garantia para o povo, notadamente para as minorias, que podem interpelar os seus governantes e intimá-los a cumprirem as promessas contidas na lei.

O direito deixa de ser instrumento de manutenção dos sistemas de dominação, adquire aspecto contestatório e de busca pela justiça. Neste modelo de Estado, o juiz deixa de ser a boca da lei e passa a ser a boca do direito. A jurisdição passa a ser um modo normal de governo, onde a justiça deixa de ser negativa e punitiva, tornando-se positiva e construtiva (GARAPON, 2001). O juiz se torna um ator essencial para o cumprimento das promessas feitas pelo legislador originário, para as gerações futuras.

Chega-se a falar em um contra positivismo ou crise do positivismo jurídico. Parece não haver mais lugar para a mera subsunção mecânica no momento da aplicação dos textos normativos. Zagrebeslky (2007) destaca que o papel do juiz em um Estado Constitucional é uma atuação especialíssima e dificílima, porque tem que fazer uma intermediação entre o Estado (como poder político-legislativo) e a sociedade (como sede dos casos que têm pretensões em nome dos princípios constitucionais).

Segundo Branco (2009), a supremacia da Constituição não se concilia com a ideia de supremacia parlamentar, o que explica o desinteresse inicial dos europeus revolucionários, em estabelecer um mecanismo que resguardasse a ordem constitucional. A defesa da Constituição era entregue de forma retórica ao próprio povo. Num contexto de supremacia parlamentar era impensável um controle da constitucionalidade das leis pelos juízes. Estes se limitavam a 
julgar segundo o texto literal da lei, que expressava a vontade do povo e não poderia ser censurado.

Os problemas da proteção da Constituição, e o seu valor jurídico, ficaram em estado de latência até as crises do Estado Liberal do final do século XIX e do primeiro quarto do século XX. Ocasião em que se constatou que o individualismo extremado era impotente para combater as crises sociais e ameaças de guerras. Neste contexto é que se desenvolve o, já mencionado, caloroso debate entre Hans Kelsen e Karl Schmitt, sobre quem deveria defender a Constituição.

A grande questão, pós-Segunda Guerra, era evitar o autoritarismo e proteger os direitos fundamentais. Consolida-se, então, o novo Estado Constitucional. E a jurisdição constitucional, nos moldes kelsenianos, alastra-se pela Europa e por todo o mundo ocidental. Parece que veio para ficar.

Tribunais constitucionais da Itália, Alemanha, França, Espanha e Portugal, demonstram que os instituidores da jurisdição constitucional conceberam-na como instância de avaliação jurídica e política da atividade legislativa, sem que essa opção resulte em politização da justiça e judicialização da política. Ressalta o Prof. Inocêncio Mártires Coelho (Coelho, 2002) que nesses países os membros das Cortes constitucionais são indicados por diferentes segmentos políticos e desempenham suas funções por tempo determinado, o que objetivamente assegura uma saudável renovação dos juízes, acompanhando as mudanças sociais.

Atualmente o juiz tem sido chamado a responder a questões políticas e sociais, dentro de um contexto em que o cidadão brasileiro está desencantado com a democracia e com o não cumprimento dos seus direitos constitucionais. Como ocorreu com os servidores públicos civis, que aguardaram por quase 20 anos a regulamentação de um direito garantido na Constituição.

O juiz deste século XXI, não é como aquele juiz que emergiu da Revolução Francesa, não é um juiz desconectado das complexas questões sociais, não é mero aplicador de uma lei que expressa a vontade da maioria popular. O juiz que advém da Revolução Americana é um juiz ativo, fortalecido com o poder não só de examinar a constitucionalidade das leis, recusar a cumprir as leis contrárias à Constituição, como também capaz de criar positivamente o direito, pela força dos precedentes judiciais (SIFUENTES, 2005). Esta transformação é resultado da transformação da própria sociedade.

Com a postura ativista ${ }^{8}$ o Judiciário brasileiro tem atendido às demandas sociais em questões nas quais não foram satisfeitos pelo legislador ordinário,

8. O termo ativismo judicial está empregado no sentido utilizado pelo discurso acadêmico e jurídico atual, ou seja, decisões não fundamentadas apenas no texto literal das leis. 
em temas como a eliminação do nepotismo, regras eleitorais, questões de saúde, previdenciárias e o direito de greve dos servidores públicos civis.

$\mathrm{O}$ direito tem um compromisso com a realização das promessas feitas às gerações futuras, com a ética e com a justiça. É a Constituição que concretiza a passagem do político para o jurídico; os fatos da vida escolhidos como essenciais, sofrem a incisão da juridicidade e se tornam parte de um ordenamento jurídico, que deve garantir a segurança e o bem-estar social de todos.

Deve ficar claro que o direito não é política no sentido de admitir escolhas livres, tendenciosas ou partidarizadas. A decisão judicial, mesmo que ativista, não possui discricionariedade plena, deve obedecer aos critérios de motivação, mediante o emprego de argumentação racional, persuasiva, independente de ideais populistas e sempre no sentido de conservar e promover os direitos fundamentais. Os riscos da judicialização e do ativismo envolvem a legitimidade democrática, a politização da justiça e a falta de capacidade institucional do Judiciário para decidir determinadas matérias. Ademais, o juiz é preparado para atuar em casos individuais e concretos, pratica a micro justiça, a macro justiça é tarefa para o legislador (BARRoso, 2009).

Ao praticar a micro justiça, o juiz tenta concretizar as promessas feitas na Constituição, mesmo que sua decisão não atinja o fim geral desejado, mas no caso concreto a promessa se realiza. Particularmente nos chamados casos difíceis, nos quais o intérprete se vê diante de direitos individuais em contraposição com direitos coletivos, como no caso da saúde.

Nos Estados Unidos, Dworkin (2005) faz uma reflexão sobre a difícil decisão de quanto gastar com saúde no seu país. A questão é ainda mais complexa quando se trata de gastar elevadíssimas quantias com apenas uma pessoa em detrimento de toda uma população. O juiz geralmente aplica o princípio do resgate, praticando a micro justiça no caso concreto, pois trata-se de salvar a vida do cidadão que pleiteia um direito à saúde perante o Judiciário. Afirma que as pessoas e os governos devem se conscientizar das dificuldades da aplicação deste princípio e chegarem ao princípio do seguro prudente, fazendo seguros de saúde e tomando medidas preventivas, o que certamente incentiva a responsabilidade individual em prol da comunidade.

Elival Ramos (2010) considera que mesmo praticando a micro justiça, o ativismo não se justifica. Independente de seu resultado o ativismo é sempre um mal, que pode atingir a democracia, um dos pilares essenciais do atual Estado brasileiro.

Com a postura ativista da Corte brasileira, já ficou demonstrada sua preocupação em viabilizar o cumprimento das promessas constitucionais, como 
ocorreu nos MI 607, 708 e 712, em que os ministros abandonaram a antiga postura defensiva para em defesa da concretização de direito fundamental, adotar nova postura positiva.

O Supremo é desta forma, um ator de papel fundamental na concretização dos direitos fundamentais. Desde que sua atitude esteja fincada na norma Constitucional e comprometida com o tipo de sociedade que se pretende construir. Uma vez que uma postura ativista nem sempre é progressista, como no caso Dred Scott vs. Sandford, nos Estados Unidos, quando a Suprema Corte americana, em uma decisão ativista, serviu aos interesses conservadores de uma elite escravocrata. ${ }^{9}$

Para que o ativismo contribua com a realização dos direitos fundamentais é essencial que o magistrado saiba com clareza e independência que tipo de Estado o legislador constituinte originário instituiu para o seu povo.

Se é um Estado Democrático e Social, é preciso que todas as decisões e atitudes sejam fundamentadas dentro dos limites traçados pela Constituição. Se for um Estado de Direito, é preciso que os direitos constitucionais sejam materializados. É necessário que os aplicadores da lei, não caiam na tentação perigosa do arbítrio, que não se sucumbam a quaisquer interesses por mais encantadores que possam parecer.

Segundo Zagrebeslky (2007), os juízes deste século não são os senhores do direito, da mesma forma que o legislador do século passado também não era; ambos são os responsáveis pela garantia necessária da coexistência entre lei, direito e justiça. Em um Estado Constitucional não existe compatibilidade

9. Este caso foi decidido pela Suprema Corte americana em 1857, teve como objeto o reconhecimento do direito à liberdade de Dred Scott. A Suprema Corte adotou postura ativista para negar direitos. É uma mancha na Corte, particularmente porque foi uma das causas da sangrenta guerra civil que dividiu aquele país. Scott era escravo africano em Missouri, acompanhando o casal, Dr. John Emerson e sua mulher Irene Marie Sandford, viveu em Estados americanos onde não havia escravidão. Após a morte de John Emerson, ajuizou em 1846, uma ação objetivando o reconhecimento de sua liberdade de Irene, sob o fundamento de que havia residido em Lllinois e Wisconsin, onde a escravidão era proibida, não podendo voltar a ser escravo no Estado de Missouri.

Em 1850, o júri acolheu a tese de Scott. Irene interpôs recurso perante a Corte Suprema de Missouri, que reformou a decisão. Scott recorreu à Suprema Corte dos Estados Unidos. Esta, pelo Min. Taney, invocou o art. II, seção 2, cláusula 1, da Constituição dos EUA que dispunha acerca da competência da Corte para julgar casos cujos cidadãos residissem em diferentes Estados. Assim, Scott não obteve seu direito à liberdade. 
com a expressão senhor do direito; mas sim, este deve ser o objeto de cuidado e responsabilidade de todos.

\section{Considerações Finals}

A pesquisa realizada demonstrou que toda a jurisdição constitucional deve conduzir para a concretização da sociedade prometida às futuras gerações e que foi transcrita no Texto Constitucional pelo legislador, legítimo representante da vontade geral do povo. Traz-se aqui o preâmbulo ${ }^{10}$ da Constituição de 1988, que independente da discussão se este seria norma ou não; parece claro que nele, o constituinte revela o tipo de Estado que pretende instituir.

Não há dúvida de que para se realizar esse modelo social pretendido há que se primar pela concretização dos direitos fundamentais. "Parece não haver qualquer dúvida de que o sistema de direitos fundamentais se converteu no núcleo básico do ordenamento constitucional brasileiro" (Cittadino, 2009, p. 12). E quanto mais o povo brasileiro adquire a consciência de seus direitos, mais ganha terreno a jurisdição constitucional, com a judicialização de questões políticas, econômicas e sociais.

Repare que o próprio legislador instituiu o mandado de injunção ${ }^{11}$ para garantir o suprimento de omissões legislativas que impeçam o exercício de direitos fundamentais. Facilitando a prática do ativismo judicial. Mesmo assim, o Supremo tem sido cauteloso na aplicação da ferramenta, mantendo uma postura contida; e só muito lentamente foi dando sentido ao mandado de injunção, como que tateando em terreno perigoso, pois os membros da Corte conhecem a difícil relação entre democracia e direitos fundamentais.

10. "Nós, representantes do povo brasileiro, reunidos em Assembleia Nacional Constituinte para instituir um Estado Democrático, destinado a assegurar o exercício dos direitos sociais e individuais, a liberdade, a segurança, o bem-estar, o desenvolvimento, a igualdade e a justiça como valores supremos de uma sociedade fraterna, pluralista e sem preconceitos, fundada na harmonia social e comprometida, na ordem interna e internacional, com a solução pacífica das controvérsias, promulgamos, sob a proteção de Deus, a seguinte Constituição Federativa do Brasil."

11. Mandado de injunção: "(...) é a medida hábil para que o postulante obtenha, em um específico caso concreto (e estritamente para ele), mediante suprimento judicial, a disciplina necessária indispensável ao exercício dos direitos e liberdades constitucionais ou das prerrogativas inerentes à nacionalidade, à soberania e à cidadania, frustrados pela ausência de norma regulamentadora, cuja falta esteja a inviabilizar-lhes o exercício" (Bandeira de Mello, 2007, p. 919). 


\section{REFERÊNCIAS BIBLIOGRÁFICAS}

Ackerman, Bruce. A nova separação dos Poderes. Rio de Janeiro: Lumen Juris, 2009. Appio. Eduardo. Controle judicial das políticas públicas no Brasil. 5. ed. Curitiba: Juruá, 2008.

Bandeira de Mello, Celso Antônio. Curso de direito administrativo. 22. ed. São Paulo: Malheiros, 2007.

Barroso, Luís Roberto. Interpretação e aplicação da Constituição. 7. ed. São Paulo: Saraiva, 2009.

Bigonha, Antonio Carlos Alpino; Moreira, Luiz. Limites do controle de constitucionalidade. Rio de Janeiro: Lumen Juris, 2009. men Juris, 2010.

Boвbio, Norberto. Teoria da norma jurídica. 2. ed. Bauru: Edipro, 2003.

BRAnco, Paulo Gustavo Gonet. Juízo de ponderação na jurisdição constitucional. São Paulo: Saraiva, 2009.

CÂnon, C. Bredlay. Defining the dimensions of judicial activism. Judicature. vol. 66. n. 6. 1983.

Canotilho, José Joaquim Gomes. Direito constitucional e a teoria da Constituição. 4. ed. Coimbra: Almedina, 1997.

. Dos discursos sobre a historicidade constitucional. Coimbra: Almedina, 2006.

Chaul, Marilena. Brasil. Mito fundador e sociedade autoritária. São Paulo: Perseu Abramo, 2007.

Cittadino, Gisele. Pluralismo, direito e justiça distributiva. Rio de Janeiro: Lumen Juris, 2009.

Coelho, Inocêncio Mártires. Constitucionalidade/inconstitucionalidade: uma questão política. Revista Diálogo Jurídico. n. 2. p. 9. Salvador: CAJ, mar. 2002.

Dworkin, Ronald. O império do direito. Trad. Jefferson Luiz Camargo. São Paulo: Martins Fontes, 1999.

Levando os direitos a sério. Trad. Nelson Boeira. São Paulo: Martins Fontes, 2002.

Uma questão de princípio. Trad. Luís Carlos Borges. São Paulo: Martins Fontes, 2005.

Ferreira Filho, Manoel Gonçalves. Estado de direito e Constituição. São Paulo: Saraiva, 1988.

FrANK, Jerome. Law and the modern mind. Glaucester: Meter Smith, 1970.

GadAmer, Hans-Georg. Verdade e método I: traços fundamentais de uma hermenêutica filosófica. Trad. Flávio Paulo Meurer. Petrópolis/Bragança Paulista: Vozes/Universitária São Francisco, 2007. 
Garapon, Antoine. O juiz e a democracia. O guardião das promessas. Rio de Janeiro: Revan, 2001.

Gasió, Guilhermo. Quién debe ser el defensor de la Constitución? Madrid: Tecnos, 1995.

Hesse, Konrad. A força normativa da Constituição. Trad. Gilmar Ferreira Mendes. Porto Alegre: Sergio Antonio Fabris Ed., 1991.

Holmes, Stephen. Precommitment and the paradox of democracy. Passion \& constraint. Chicago: Universidaty of Chicago Press, 1995.

Kelsen, Hans. Jurisdição constitucional. São Paulo: Martins Fontes, 2007.

KRAMER, D. Larry. Democracia deliberativa e constitucionalismo popular: James Madison e o "interesse do homem". In: Bigonha, Antonio Carlos Alpino; Moreira, Luiz (orgs.). Limites do controle de constitucionalidade. Rio de Janeiro: Lumen Juris, 2009.

Lassale, Ferdinand. A essência da Constituição. Rio de Janeiro: Lumem Juris, 1998.

Leal, Saul Tourinho. Ativismo ou altivez? O outro lado do Supremo Tribunal Federal. Belo Horizonte: Fórum, 2010.

Lyra Filho, Roberto.O que é direito. São Paulo: Brasiliense, 2007.

Locke, John. Segundo tratado sobre o governo. São Paulo: Martin Claret, 2002.

Luhmann, Niklas. Sociologia do direito. Rio de Janeiro: Tempo brasileiro, 1983. vol. 1.

Maus, Ingeborg. O Judiciário como superego da sociedade. Rio de Janeiro: Lumen Juris, 2010.

Mendes, Gilmar Ferreira; Branco, Paulo Gustavo Gonet; Coelho, Inocêncio Mártires. Curso de direito constitucional. 2. ed. São Paulo: Saraiva, 2008.

Montesquieu, Charles Louis de Secondat. Do espírito das leis. São Paulo: Abril Cultural, 1979.

Moreira, Luiz. A Constituição como simulacro. Rio de Janeiro: Lumen Juris, 2007.

Oliveira, Marcelo Andrade Cattoni de. Tutela jurisdicional e Estado Democrático de Direito. Por uma compreensão adequada do mandado de injunção. Belo Horizonte: Del Rey, 1998.

Ost, François. O tempo do direito. Bauru: Edusc, 1999.

Pogrebinschi, Thamy. Ativismo judicial e direito: considerações sobre o debate contemporâneo. Direito, Estado e sociedade. Rio de Janeiro: PUC, 2000.

Ramos, Elival da Silva. Ativismo judicial. Parâmetros dogmáticos. São Paulo: Saraiva, 2010.

Rawls, John. Theory of justice. Cambridge. Harvard University Press, 1977.

Rosenfeld, Michel. Jurisdição constitucional na Europa e nos Estado Unidos: paradoxos e contrastes. In: Bigonha, Antonio Carlos Alpino; Moreira, Luiz (orgs.). Limites do controle de constitucionalidade. Rio de Janeiro: Lumen Juris, 2009. 
Rosseau, Jean-Jacques. O contrato social. Lisboa: Publicações Europa-América, 1981.

Sebastià, César Arjona. Los votos discrepantes del juez O. W. Holmes. Madrid: Iustel, 2006.

SifUENTES, Mônica. Súmula vinculante. Um estudo sobre o poder normativo dos Tribunais. São Paulo: Saraiva, 2005.

Valle, Vanice Regina Lírio do et al. Ativismo jurisdicional e o Supremo Tribunal Federal. Curitiba: Juruá, 2009.

VIANA, Luiz Werneck et al. A judicialização da política e das relações sociais no Brasil. Rio de Janeiro: Revan, 1999.

VieIRA, Oscar Vilhena. A Constituição e sua reserva de justiça. Um ensaio sobre os limites materiais ao poder de reforma. São Paulo: Malheiros, 1999.

Zagrebelsky, Gustavo. El derecho dúctil. 7. ed. Madrid: Giulio Einaudi Ed., 2007.

\section{Pesquisas do Editorial}

\section{Veja também Doutrina}

- As Cortes de Warren e Rehnquist: judicial activism ou judicial self-restraint, de Artur César de Souza - RT 874/11;

- Expansão da jurisdição constitucional e separação de Poderes: uma análise sistêmica à luz da cidadania, de Eduardo Cambi e Diego Nassif - RT 916/249;

- Jurisdição constitucional e democracia na Constituição brasileira: entre o ativismo e a autocontenção, de Pedro Scalco - RT 880/78; e

- 0 novo papel do Judiciário e a teoria da separação dos Poderes: judicialização de direitos?, de Livia Regina Savergnini Bissoli Lage - RePro 184/163. 